\title{
Effects of Serotonin and Serotonergic Agonists and Antagonists on the Production of Interferon- $\gamma$ and Interleukin-10
}

\author{
Marta Kubera, Ph.D., Gunter Kenis, M.S., Eugene Bosmans, Ph.D., Simon Scharpé, Ph.D., \\ and Michael Maes, M.D., Ph.D.
}

\begin{abstract}
Serotonin (5-HT) is a neurotransmitter and an immune modulator. In vitro, antidepressants with a serotonergic mode of action have, at concentrations within the therapeutical range, negative immunoregulatory effects, i.e., they increase the production rate of interleukin-10 (IL-10), a negative immunoregulatory cytokine. We have hypothesized that part of these effects may be explained by the serotonergic activities of antidepressants on immunocytes. This study was carried out to examine the effects of 5-HT, p-chlorophenylalanine (PCPA), a 5-HT depleting agent, flesinoxan (a 5-HT1A agonist), m-chlorophenylpiperazine ( $m C P P ; a$ 5-HT2A/2C agonist), and ritanserin (a 5-HT2A/ $2 C$ antagonist) on the production rate of interferon- $\gamma$ (IFN $\gamma$ ), a proinflammatory cytokine, and IL-10 by whole blood stimulated with polyclonal activators. The IFN $\gamma / I L-$ 10 production ratio was computed, since this ratio reflects the pro-versus anti-inflammatory capacity of cultured
\end{abstract}

whole blood. We found that: 1) 5-HT, $150 \mathrm{ng} / \mathrm{mL}, 1.5 \mu \mathrm{g} /$ $m L$, and $15 \mu \mathrm{g} / \mathrm{mL}$ significantly decreased the IFN $\gamma / \mathrm{IL}-10$ ratio; 2) PCPA (5 $\mu \mathrm{M})$ significantly suppressed the production of IFN $\gamma$ and IL-10; 3) flesinoxan $(15 \mathrm{ng} / \mathrm{mL} ; 1.5$ $\mu \mathrm{g} / \mathrm{mL}$ ) had no significant effects on the production of the above cytokines; and 4) $m C P P(2.7 \mu \mathrm{g} / \mathrm{mL})$ and ritanserin $(5.0 \mu \mathrm{g} / \mathrm{mL})$ suppressed the IFN $\gamma / \mathrm{IL}-10$ ratio. It is concluded that intracellular 5-HT may be necessary for an optimal synthesis of IFN $\gamma$ and IL-10, and that extracellular 5-HT concentrations at or above serum values may suppress the production of the proinflammatory cytokine IFN $\gamma$. The negative immunoregulatory effects of antidepressive drugs are probably not related to their serotonergic activities. [Neuropsychopharmacology 23:89-98, 2000] (C) 2000 American College of Neuropsychopharmacology. Published by Elsevier Science Inc. All rights reserved
KEY WORDS: Serotonin; Cytokines; Cell-mediated immunity; Antidepressants; 5-HT receptors; Depression

From the Clinical Research Center for Mental Health, Anwerp, Belgium (MK, MM); Institute of Pharmacology, Polish Academy of Sciences, Department of Endocrinology, Krakow, Poland (MK); Eurogenetics, Tessenderlo, Belgium (GK, EB); Department of Medical Biochemistry, University of Antwerp, Edegem, Belgium (SS); Department of Psychiatry, Vanderbilt University, Nashville, USA (MM); Department of Psychiatry \& Neuropsychology, University of Maastricht, Maastricht, The Netherlands (MM); and IRCCS, Fatebenefratelli, Brescia, Italy (MM).

Address correspondence to: Michael Maes, M.D., Ph.D., Department of Psychiatry \& Neuropsychology, University Hospital of Maastricht, PO Box 5800, 6202 AZ Maastricht, The Netherlands.

Received July 28, 1999; revised November 4, 1999; accepted November 16, 1999.
Serotonin (5-hydroxytryptamine, 5-HT) is a neurotransmitter, a vasoactive amine released by platelets at sites of inflammation and an immune modulator (Roszman et al. 1985; Mossner and Lesch 1998; Kubera and Maes 1999). In humans, 5-HT is produced, outside the central nervous system, by enterochromaffin cells and it is stored in circulating platelets and to a lesser extent in monocytes and lymphocytes (Essmann 1978). 5-HT is released from platelets and lymphocytes/monocytes following stimulation by platelet activating factors or lectins/interferon- $\gamma($ IFN $\gamma$ ), respectively (Finocchiaro et al. 1988). Moreover, it has been demonstrated that lymphoid organs are innervated by serotonergic neurons and that 5-HT may influence the proliferation and dif- 
ferentiation of immunocompetent cells (Cohen et al. 1985; Felten et al. 1991). Pharmacological and molecular analyses have confirmed the presence of 5HT1A and $5 \mathrm{HT} 2 \mathrm{~A} / \mathrm{C}$ receptors on activated human immunocytes and specific 5-HT transporter sites on macrophages/ lymphocytes (Aune et al. 1994).

The effect of 5-HT on cell-mediated immunity and on the inflammatory response system (IRS) is still a matter of controversy. Some studies show that 5-HT has immunosuppressive effects. Devoino et al. (1968) reported that substances, which have the property to increase 5-HT concentrations, inhibit immunogenesis and antibody production in rodents. 5-HT may suppress delayed hypersensitivity and transplantation immunity (for review see Devoino and Morozova 1988). Bonnet et al. (1984) found that 5-HT suppresses murine lymphocytic response to phytohemagglutinin A (PHA) and/or allogeneic cells. p-Chlorophenylalanine (PCPA), an inhibitor of 5-HT synthesis, enhances the production of antibodies (Jackson et al. 1985). Other immune functions, however, may be stimulated by 5 -HT. For example, cutaneous injection of 5-HT can initiate a delayed-type hypersensitivity reaction through local recruitment and activation of CD4 $4^{+}$T-helper cells (Ptak et al. 1991). Low doses $(100 \mathrm{ng} / \mathrm{ml})$ of exogenously added 5-HT stimulate $\mathrm{T}$ cell proliferation in response to interleukin-2 (IL-2) (Young et al. 1993; Young and Mathews 1995). Enhancement of murine T-cell blastogenesis by 5 -HT has been shown to occur through the 5-HT2 receptor (Young et al. 1993), whereas activation of human $\mathrm{T}$ cells may occur through 5-HT1A receptors (Aune et al. 1994). Jahnova (1994) showed immuno-activating effects of 5-HT on the production of antibodies. Boranic et al. (1987), on the other hand, reported that 5-HT as well as PCPA suppressed antibody production.

The effects of 5-HT on the production of cytokines by human immunocytes was the subject of a few studies. Arzt et al. (1991) showed that 5-HT inhibits, in a concentration-dependent way, the LPS-induced production of tumor necrosis factor by human macrophages. This effect was blocked by the 5-HT2 receptor antagonist, ketanserin. In humans, 5-HT promotes IFN $\gamma$ production by NK cells probably through a 5HT1A receptor mediated mechanism (Hellestrand et al. 1993).

There is now evidence that major depression is accompanied by disorders in the peripheral and central turnover of 5-HT (for review see Maes and Meltzer 1995). There is also evidence that the production rate of proinflammatory cytokines, such as IL-1, IL-6 and IFN $\gamma$ is increased in patients with major depression (for review see Maes 1997; Connor and Leonard 1998; Seidel et al. 1995; Sluzewska et al. 1995). It is hypothesized that the increased production of the above cytokines may play a role in the etiology of depression (Maes et al. 1995; Yirmiya 1996, 1997; Connor and Leonard 1998). Indeed, IL-1, IL-6, and IFN $\gamma$ given to experimental ani- mals and humans may produce depressive symptoms or full blown major depression (for review see Maes 1997; Bluthé et al. 1992; Yirmiya 1996).

It is thought that antidepressants, such as selective 5-HT reuptake inhibitors (SSRIs), 5-HT-noradrenaline reuptake inhibitors (SNRIs) and some tricyclic antidepressants (TCAs) exert their antidepressant activity through modulation of the brain serotonergic system (for review see Maes and Meltzer 1995). Antidepressants have also significant negative immunoregulatory activities. In depressed patients, prolonged treatment with SSRIs normalizes the initially increased production of IL-6, IFN $\gamma$, and positive acute phase proteins (Seidel et al. 1995; Sluzewska et al. 1995; Maes et al. 1997). In vitro, co-incubation of human whole blood with SSRIs (fluoxetine, sertraline), an SNRI (venlafaxine), TCAs (imipramine, clomipramine), a reversible MAO-A inhibitor (RIMA; moclobemide, and L-5-HTP, the immediate precursor of 5-HT, significantly increased the production of IL-10 and/or decreased that of IFN $\gamma$ (Maes et al. 1999; Lin et al. in press; Kubera and Maes 1999). The results suggest that antidepressants with a serotonergic mode of action have, at concentrations within the therapeutical range, negative immunoregulatory effects. The exact mechanisms by which antidepressive drugs affect cytokine production have remained elusive. It may be hypothesized that part of these effects may be explained by the serotonergic activities of antidepressants (for review see Maes and Meltzer 1995), such as depletion of intracellular 5-HT stores, increased extracellular 5-HT, 5-HT2A/2C receptor blockade, or 5-HT1A receptor stimulation. However, to the best of our knowledge, the effects of serotonergic agonists and antagonists on the production of IFN- $\gamma$ and IL-10 have not been studied as yet.

The specific aims of the present study were to examine the effects of 5-HT, PCPA (a 5-HT depleting agent), flesinoxan (a 5-HT1A agonist), mCPP (a 5-HT2A/2C agonist), and ritanserin (a 5-HT2A/2C antagonist) on the production rate of IFN $\gamma$ and IL-10 by whole blood stimulated with polyclonal activators. The results of the present study provide a critical test to elucidate whether serotonergic mechanisms modulate the production of IFN $\gamma$ and IL-10; and whether the effects of antidepressants on these cytokines are mediated by serotonergic mechanisms.

\section{MATERIALS AND METHODS}

\section{Subjects}

Blood samples for the assay of IL-10 and IFN $\gamma$ were collected from 26 subjects, i.e., 19 healthy volunteers, divided into two subgroups according to age $(<45$ years versus $\geqslant 45$ years), and seven major depressed patients who suffered from treatment resistant depression 
(TRD). The mean ages and male/female ratio of these subgroups were: 12 younger volunteers (mean age $=$ $35.4 \pm 9.6$ years, male /female ratio: $5 / 7$ ); 7 older volunteers (mean age $=51.6 \pm 1.7$ years, male/female ratio: $2 / 5$ ); and TRD patients (mean age $=50.6 \pm 3.9$ years, male/female ratio: $2 / 5$ ). The normal volunteers had a negative past and present history of axis-I psychiatric illnesses. None was a regular drinker and none had ever been taking antidepressant or antipsychotic drugs.

All subjects, i.e., normal volunteers and depressed patients, were free of medical illness, and were free of acute infections, as well as inflammatory or allergic reactions for at least two weeks prior to the study. They were free of drugs known to modify the immune or endocrine functions for at least one month before blood was sampled. All subjects abstained from caffeine, nicotine, and alcohol for at least $12 \mathrm{hr}$ before blood was sampled. The depressed patients were admitted to the University Department of Psychiatry, AZ Stuivenberg, Antwerp, Belgium. Patients fulfilled with the DSM-IV diagnostic criteria for major depression (American Psychiatric Association, 1994). We used the Structured Clinical Interview for DSM-III-R, Patient Version to make the diagnosis (Spitzer et al. 1990). The depressed patients were resistant to treatment with fluoxetine, 20$60 \mathrm{mg}$ daily, administered daily for at least six weeks. Patients were still taking fluoxetine when blood was sampled. The mean Hamilton Depression Rating Scale score (17-item version) (Hamilton 1960) in the depressed patients was 25.1 ( \pm 3.2). All subjects gave written informed consent after the study design was fully explained.

\section{Methods}

After an overnight fast, blood for the assays of IFN $\gamma$ and IL-10 was taken at 9 a.m. ( $\pm 30 \mathrm{~min}$ ). The effects of the serotonergic agents on these cytokines were examined by stimulating $1 / 10$ diluted whole blood with PHA $(1 \mu \mathrm{g} / \mathrm{ml}$; Murex Diagnostics Ltd, Dartford, England) and LPS $(5 \mu \mathrm{g} / \mathrm{ml}$ (E.Coli 026 lyophylized and sterilized by gamma-irradiation); Sigma, Belgium). Diluted whole blood stimulated with PHA + LPS offers the most appropriate and reproducible culture condition in order to measure cytokine production (Zangerle et al. 1992; De Groote et al. 1992, 1993). Diluted whole blood cultures reflect the in-vivo immune cellular and humoral interactions and may be employed to examine the effects of drugs on cytokine secretion (Zangerle et al. 1992; De Groote et al. 1992, 1993; Maes et al. 1998). A total of $1.8 \mathrm{ml}$ of RPMI-1640 medium with L-glutamine (Gibco BRL) supplemented with $100 \mathrm{IU} / \mathrm{mL}$ penicillin (Sigma), $100 \mu \mathrm{g} / \mathrm{mL}$ streptomycin (Sigma), and PHA + LPS were placed into 24 well cell culture plates (Falcone 3047; Becton Dickonsen). The serotonergic substances were dissolved in sterile water, whereas sterile water alone served as the corresponding control. Twenty microliters of each serotonergic drug solution was added to the wells and gently mixed with the medium. A total of $0.2 \mathrm{ml}$ of whole blood from each of 26 subjects were cultured with 5-HT $(150 \mathrm{ng} / \mathrm{mL}, 1.5 \mu \mathrm{g} / \mathrm{mL}$ and $15 \mu \mathrm{g} /$ $\mathrm{mL})$, PCPA $(5 \mu \mathrm{M})$, flesinoxan $(15 \mathrm{ng} / \mathrm{mL}$ and $1.5 \mu \mathrm{g} /$ $\mathrm{mL}), \mathrm{mCPP}(27 \mathrm{ng} / \mathrm{mL}$ and $2.7 \mu \mathrm{g} / \mathrm{mL})$, and ritanserin (50 ng/mL and $5.0 \mu \mathrm{g} / \mathrm{mL}$ ).

The viability of cells was checked by ethidium-bromide-dye exclusion. The samples were incubated for 24 hours in a humidified atmosphere at $37^{\circ} \mathrm{C}$, and $5 \% \mathrm{CO} 2$. Supernatants were taken off carefully under sterile conditions, divided into eppendorf tubes, and frozen immediately at $-75^{\circ} \mathrm{C}$. IFN $\gamma$ and IL-10 were quantified by means of ELISA methods (Eurogenetics, Tessenderlo, Belgium) based on appropriate and validated sets of monoclonal antibodies as described by us previously (Maes et al. 1999). All assays of IFN $\gamma$ or IL-10 were carried out on the same day in one run by the same operator (AL). The intra-assay CV values for both analytes were less than $8 \%$. In our laboratory, the detection limits are $0.9 \mathrm{U} / \mathrm{mL}$ for IFN $\gamma$ and $10 \mathrm{pg} / \mathrm{mL}$ for IL-10.

\section{Statistics}

Repeated measure design analyses of variance (RM ANOVAs) were used to examine the: 1) within-subject variability with the effects of serotonergic drugs as temporal condition, i.e., the positive control versus each of the serotonergic drugs at the different concentrations; and 2) between-subject variability with the three study groups (younger volunteers, elderly volunteers, and depressed patients) and gender as factors. All results of RM design ANOVAs were corrected for sphericity. Tests on simple effects were employed to clarify main effects or significant interactions. A simple effect is the effect of one variable at one level of the other variable. Differences among treatment means were ascertained by means of the Dunn test. In order to examine the ratio of the secretion of pro-inflammatory (IFN $\gamma$ ) versus negative immunoregulatory (IL-10) cytokines, the IFN $\gamma / \mathrm{IL}-$ 10 ratio was computed as: $\mathrm{z}$ transformed IFN $\gamma$ and $\mathrm{z}$ transformed IL-10 (Maes et al. 1998). IFN $\gamma$ and IL-10 and their ratio were processed in Box-Cox transformation.

\section{RESULTS}

Figure 1 shows the effects of 5-HT on the production of IFN $\gamma$ and IL-10. RM design ANOVA showed a significant drug effect on IFN $\gamma$ production $(\mathrm{F}=11.8, \mathrm{df}=3$ / $85, p=.00002)$, but no significant drug $X$ group interaction $(\mathrm{F}=0.92, \mathrm{df}=6 / 85, p=.5)$. Dunn tests showed significantly lower IFN $\gamma$ production in the 5-HT 1.5 $\mu \mathrm{g} / \mathrm{mL}(\mathrm{t}=2.89, p=.005)$ and $15 \mu \mathrm{g} / \mathrm{mL}(\mathrm{t}=5.86, p=$ $.000007)$, but not $150 \mathrm{ng} / \mathrm{mL}(\mathrm{t}=2.02, p=.04)$ condi- 
tions than in the control condition (tested at $p=.017$ ). RM design ANOVA showed no significant drug effects on IL-10 production ( $\mathrm{F}=2.2, \mathrm{df}=2 / 74, p=.1)$, although there was a significant drug $\mathrm{X}$ group effect $(\mathrm{F}=2.9, \mathrm{df}=$ $5 / 74, p=.018)$. Analyses on simple effects showed a significant drug effect in elderly volunteers $(\mathrm{F}=5.1 \mathrm{df}=$ $3 / 90, p=.003)$, but not in younger volunteers $(\mathrm{F}=2.2$, $\mathrm{df}=3 / 90, p=.09)$ or major depressed patients $(\mathrm{F}=0.6$, $\mathrm{df}=3 / 90, p=.6$ ). In elderly normal volunteers, Dunn tests showed significant suppressant effects of 5-HT at the $1.5 \mu \mathrm{g} / \mathrm{mL}(\mathrm{t}=5.41, p=.00001)$ and $15 \mu \mathrm{g} / \mathrm{mL}(\mathrm{t}=$ $4.23, p=.0002)$, but not at $150 \mathrm{ng} / \mathrm{mL}(\mathrm{t}=1.93, p=.05)$ (tested at $p=.017$ ).

RM design ANOVA performed on the IFN $\gamma / \mathrm{IL}-10$ ratio showed a significant drug effect $(\mathrm{F}=13.9, \mathrm{df}=2$ / $74, p=.00005)$, but no significant drug $\mathrm{X}$ group interaction $(\mathrm{F}=1.8, \mathrm{df}=5 / 74, p=.1)$. Dunn tests showed that the IFN $\gamma /$ IL-10 ratio was significantly lower at the 5HT $150 \mathrm{ng} / \mathrm{mL}(\mathrm{t}=4.27, p=.0002), 1.5 \mu \mathrm{g} / \mathrm{mL}(\mathrm{t}=$ 2.64, $p=.009)$ and $15 \mu \mathrm{g} / \mathrm{mL}(\mathrm{t}=6.24, p=.000003)$ conditions than in the control condition.

Figure 1 shows the effects of PCPA on the production of IFN $\gamma$ and IL-10. RM design ANOVAs showed significant drug effects on IFN $\gamma(\mathrm{F}=110, \mathrm{df}=1 / 31, p<$ $\left.10^{-5}\right)$ and IL-10 $\left(\mathrm{F}=95.5 \mathrm{df}=1 / 30, p<10^{-5}\right)$, but no significant drug $x$ group interactions for $\operatorname{IFN} \gamma(\mathrm{F}=2.1$, $\mathrm{df}=2 / 31, p=.1)$ or IL-10 $(\mathrm{F}=1.6, \mathrm{df}=2 / 30, p=.2)$. There were no significant effects of PCPA on the IFN $\gamma$ / IL-10 ratio $(\mathrm{F}=0.3, \mathrm{df}=1 / 30, p=.6)$ and no significant group $\mathrm{X}$ drug interaction ( $\mathrm{F}=0.4, \mathrm{df}=2 / 30, p=.7$ ).

RM design ANOVAs did not show any significant effects of flesinoxan (at the two concentrations) on $\operatorname{IFN} \gamma(\mathrm{F}=1.8, \mathrm{df}=2 / 61, p=.2), \mathrm{IL}-10(\mathrm{~F}=0.4, \mathrm{df}=2$ / $51, p=.7)$, or the IFN $\gamma / \mathrm{IL}-10$ ratio $(\mathrm{F}=0.7, \mathrm{df}=1 / 41$, $p=.6)$. There were no significant group $\mathrm{X}$ drug interaction patterns for IFN $\gamma(\mathrm{F}=0.2, \mathrm{df}=4 / 61, p=.9)$, IL-10 $(\mathrm{F}=1.4, \mathrm{df}=3 / 51, p=.2)$, or the IFN $\gamma / \mathrm{IL}-10$ ratio $(\mathrm{F}=$ $0.7, \mathrm{df}=3 / 41, p=.5)$.

Figure 2 shows the effects of $\mathrm{mCPP}$ and ritanserin on the production of IFN $\gamma$ and IL-10. RM design ANOVAs showed that there were no significant effects of $\mathrm{mCPP}$ on $\operatorname{IFN} \gamma(\mathrm{F}=2.2, \mathrm{df}=2 / 61, p=.1)$ and IL-10 ( $\mathrm{F}=1.5$, $\mathrm{df}=2 / 51, p=.2)$. The interaction pattern group $\mathrm{X}$ drug was not significant for IFN $\gamma(\mathrm{F}=1.0, \mathrm{df}=4 / 61, p=.4)$ and IL-10 ( $\mathrm{F}=1.5 \mathrm{df}=3 / 51, p=.2)$. RM design ANOVA showed that there was a significant effect of $\mathrm{mCPP}$ on the IFN $\gamma / \mathrm{IL}-10$ ratio $(\mathrm{F}=3.7, \mathrm{df}=2 / 57, p=$ .03), but no significant group $\mathrm{x}$ drug interaction $(\mathrm{F}=$ 1.6 , $\mathrm{df}=4 / 57, p=.2$ ). Dunn tests (tested at $p=.025$ ) showed that the IFN $\gamma /$ IL-10 ratio was significantly lower in the mCPP $2.7 \mu \mathrm{g} / \mathrm{mL}$ condition $(\mathrm{t}=0.25, p=$ $.8)$, but not $27 \mathrm{ng} / \mathrm{mL}(\mathrm{t}=0.25, p=.8)$ condition, than in the control condition.

RM design ANOVA showed a significant effect of ritanserin on the production of IFN $\gamma(\mathrm{F}=5.2, \mathrm{df}=2$ / $58, p=.008)$, but no significant group $\mathrm{x}$ drug interac- tion $(\mathrm{F}=1.7, \mathrm{df}=4 / 58, p=.2)$. Dunn tests (performed at $p=.025$ ) showed a significantly lower IFN $\gamma$ production in the ritanserin $5.0 \mu \mathrm{g} / \mathrm{mL}(\mathrm{t}=3.15, p=.003)$, but not in the $50 \mathrm{ng} / \mathrm{mL}(\mathrm{t}=0.96, p=.8)$ condition than in the control condition. RM design ANOVA did not show significant effects of ritanserin on the production of IL-10 ( $\mathrm{F}=1.7, \mathrm{df}=2 / 58, p=.2)$ and no significant group $\mathrm{X}$ drug interactions $(\mathrm{F}=1.3, \mathrm{df}=4 / 58, p=.3)$. RM design ANOVA showed a significant effect of ritanserin on the IFN $\gamma / \mathrm{IL}-10$ ratio $(\mathrm{F}=5.7, \mathrm{df}=2 / 55, p=$ .006), but no significant group $\mathrm{X}$ drug interaction $(\mathrm{F}=$ $2.1, \mathrm{df}=4 / 55, p=.09$ ). Dunn tests showed a significantly lower IFN $\gamma / \mathrm{IL}-10$ ratio in the ritanserin $5.0 \mu \mathrm{g} / \mathrm{mL}$ condition $(\mathrm{t}=2.98, p=.004)$, but not $50 \mathrm{ng} / \mathrm{mL}(\mathrm{t}=0.15, p=$ .9) condition, than in the control condition.

RM design ANOVAs showed significant differences in culture supernatant IFN $\gamma(\mathrm{F}=3.9, \mathrm{df}=2 / 31, p=.03)$, but not IL-10 ( $\mathrm{F}=1.8, \mathrm{df}=2 / 30, p=.2)$ or the IFN $\gamma /$ IL-10 ratio $(\mathrm{F}=0.4, \mathrm{df}=2 / 30, p=.7)$ between the study groups. Dunn tests (performed at $p=.017$ ) showed significant lower IFN $\gamma$ production in elderly than in younger volunteers $(\mathrm{t}=2.64, p=.012)$ and major depressed patients $(\mathrm{F}=3.14, p=.004)$. There were no significant differences in IFN $\gamma$ production between younger volunteers and major depressed patients $(\mathrm{t}=$ $0.51, p=.6)$.

\section{DISCUSSION}

The major findings of this study are that: 1) 5-HT, 150 $\mathrm{ng} / \mathrm{mL}, 1.5 \mu \mathrm{g} / \mathrm{mL}$, and $15 \mu \mathrm{g} / \mathrm{mL}$, significantly decreased the IFN $\gamma /$ IL-10 ratio; 2) PCPA significantly suppressed the production of IFN $\gamma$ and IL-10; 3) flesinoxan had no significant effects on the production of the above cytokines; and 4) the higher concentrations of $\mathrm{mCPP}$ and ritanserin suppressed the IFN $\gamma / \mathrm{IL}-10$ ratio. Since IFN $\gamma$ is a proinflammatory cytokine and IL-10 an anti-inflammatory cytokine, our results suggest that 5-HT, $\mathrm{mCPP}$ and ritanserin may have negative immunoregulatory effects. IFN $\gamma$ is produced by activated Th1 ( $\mathrm{T}$ helper-1) lymphocytes and by natural killer cells. IL-10 is produced by a variety of cells, including $\mathrm{T}$ lymphocytes, B lymphocytes, and monocytes. Thus, its expression is not confined to a particular $\mathrm{T}$ cell subset (Th-1 like) as in the rodent (Cavaillon 1996). IL-10 was originally characterized as a factor which inhibits the secretion of IFN $\gamma$ by Th1 cell clones (Murray et al. 1997). Moreover, IL-10 downregulates the production of monocytic cytokines (Cavaillon 1996). The ratio of IFN $\gamma$ to IL-10 in culture supernatants is of critical importance in determining the pro- or anti-inflammatory capacity of culture supernatants (Katsikis et al. 1995).

Previously, it has been found that 5-HT concentrations, close to the physiological concentrations, have immuno-stimulating effects, whereas higher concentra- 
SEROTONIN
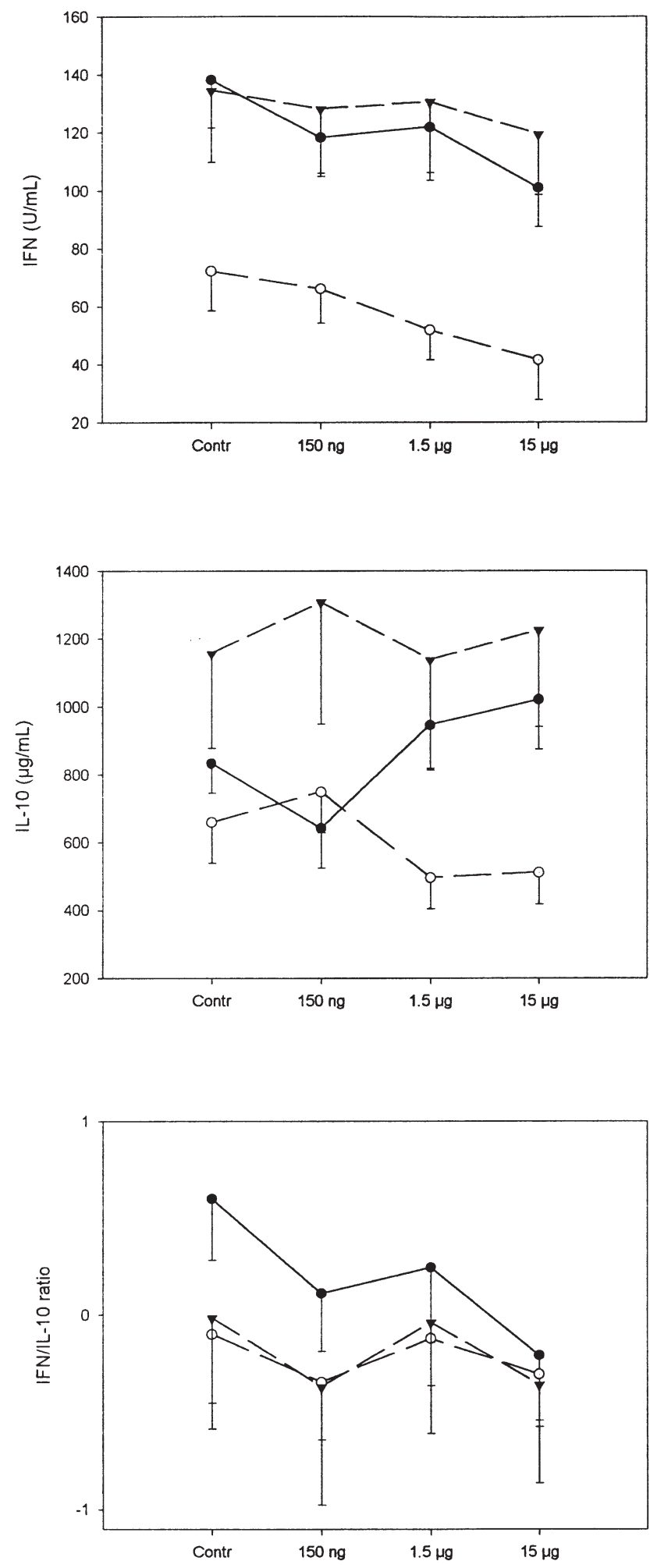

pcpA
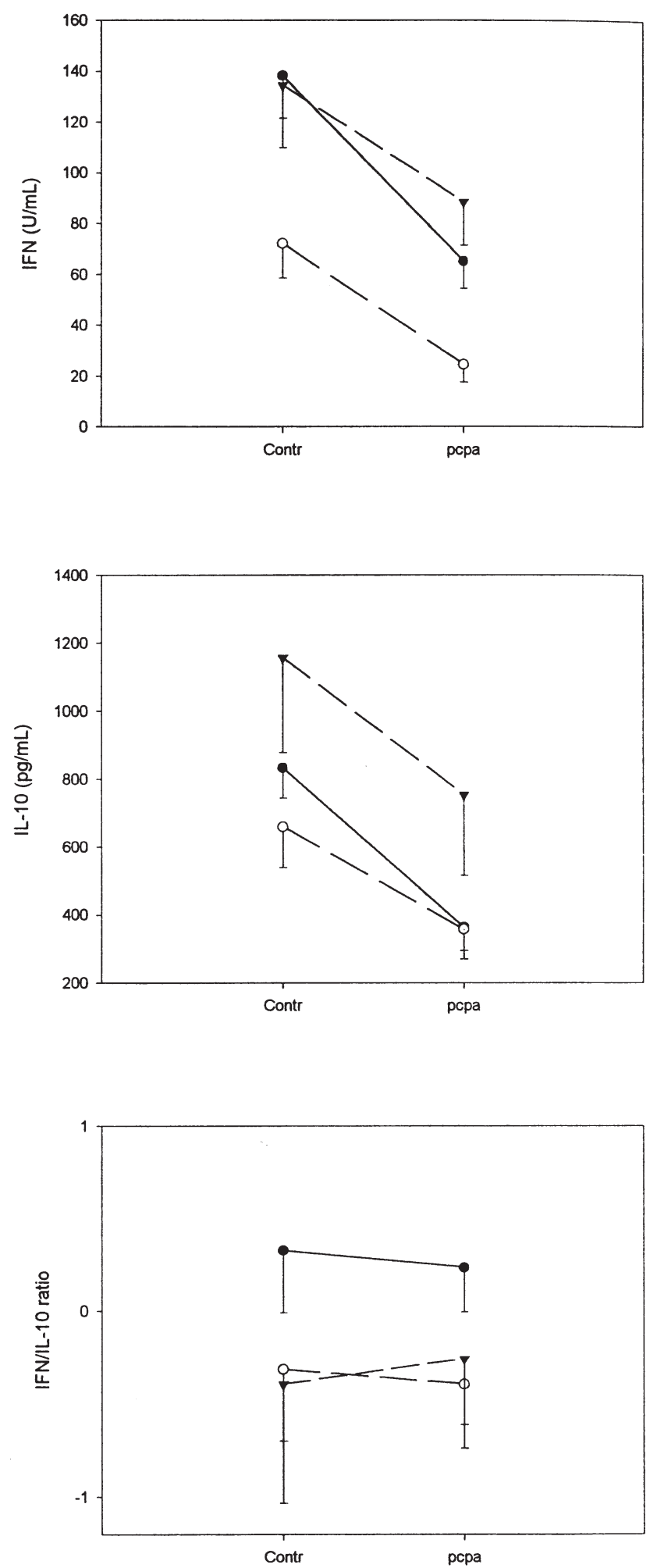

Figure 1. Effects of serotonin (5-HT, $150 \mathrm{ng} / \mathrm{mL}, 1.5 \mu \mathrm{g} / \mathrm{mL}$, and $15 \mu \mathrm{g} / \mathrm{mL}$ ) and p-chlorophenylalanine (PCPA, $5 \mu \mathrm{M})$ on the stimulated production of interferon- $\gamma($ IFN $\gamma$ ) and interleukin-10 (IL-10) and on the IFN $\gamma /$ IL-10 ratio. O: Younger normal volunteers; $\bigcirc$ : Older normal volunteers; $\mathbf{\nabla}$ : Treatment resistant major depressed patients. 
mCPP
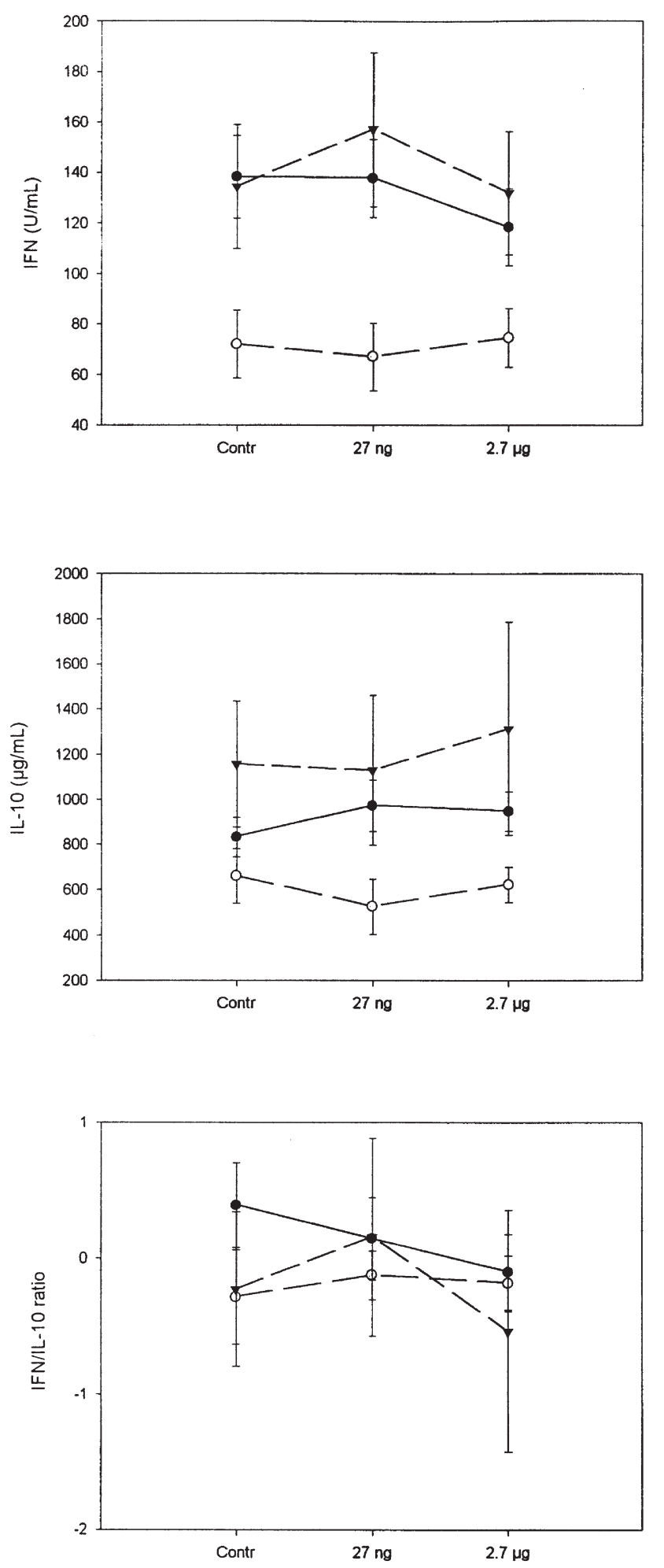

RITANSERIN
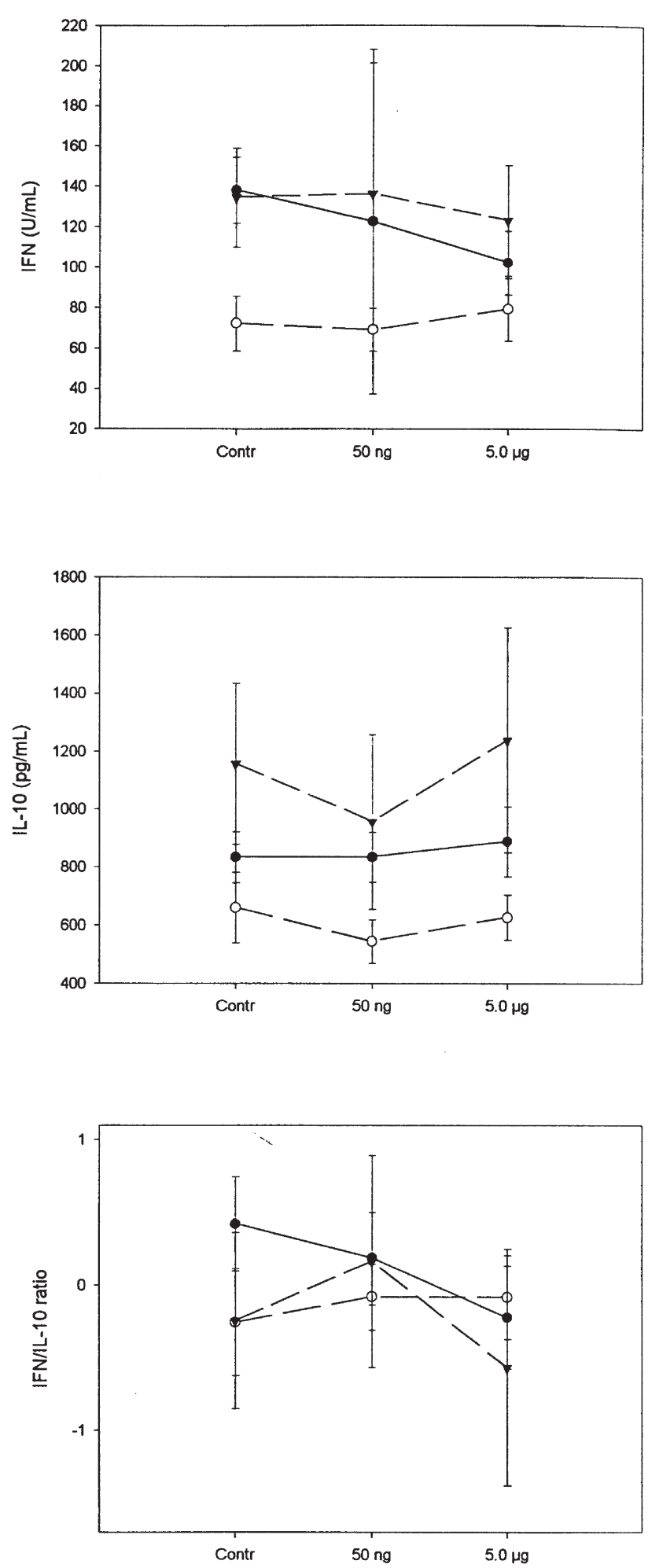

Figure 2. Effects of m-chlorophenylpiperazine (mCPP, $27 \mathrm{ng} / \mathrm{mL}$ and $2.7 \mu \mathrm{g} / \mathrm{mL}$ ), and ritanserin $(50 \mathrm{ng} / \mathrm{mL}$ and $5.0 \mu \mathrm{g} /$ $\mathrm{mL}$ ) on the stimulated production of interferon- $\gamma(\mathrm{IFN} \gamma)$ and interleukin-10 (IL-10) and on the IFN $\gamma / \mathrm{IL}-10$ ratio. O: Younger normal volunteers; $\bigcirc$ : Older normal volunteers; $\mathbf{\nabla}$ : Treatment resistant major depressed patients. 
tions have immunosuppressive effects (Aune et al. 1994; Roszman et al. 1985; Bonnet et al. 1984). The baseline concentrations of 5-HT in serum are between 50 and $200 \mathrm{ng} / \mathrm{mL}$, whereas under pathological conditions such as inflammation, ischemia, or trombosis, extracellular 5-HT levels may increase to $3 \mu \mathrm{M}$. Thus, in the present study we employed 5-HT at concentrations found in normal serum and during pathological conditions. It has been reported that both $\mathrm{T}$ cells and monocytes release 5-HT in culture medium after PHA stimulation and that concentrations of 5-HT between $10^{-8} \mathrm{M}$ to $10^{-7} \mathrm{M}$, sufficient to activate 5 -HT receptors, can be reached in these cultures. We found that 5-HT at all concentrations lowered the IFN $\gamma /$ IL-10 ratio, an effect which mainly could be ascribed to the suppressive effects on IFN $\gamma$ secretion. These findings extend those of Bonnet et al. (1984) and Devoino and Morozova (1988) who reported that exogenous 5-HT may suppress various aspects of cell-mediated immunity. Devoino et al. (1968) suggested that these changes might be related to central rather than to peripheral 5-HT activities, because lesions of the serotonergic raphe nuclei promoted stimulation in immune responsivity. Nevertheless, our results show that 5-HT has direct effects on peripheral blood immunocytes. Our results also suggest that the suppressive effects of antidepressive drugs on the IFN $\gamma /$ IL-10 ratio are probably not related to direct effects of 5-HT. Indeed, the present study showed that 5-HT significantly suppressed the production of IFN $\gamma$, whereas the common activity of different antidepressants, such as SSRIs, TCAs, HCAs, RIMAs, and L-5-HTP is to increase IL-10 secretion, rather than decreasing that of IFN $\gamma$.

The second major finding of this study is that PCPA, an agent which inhibits 5-HT synthesis, dramatically suppressed the production of both IFN $\gamma$ and IL-10. Since monocytes and lymphocytes may synthesize 5-HT (Finocchiaro et al. 1988), coincubation of whole blood with PCPA most likely inhibits 5-HT synthesis in lymphocytes and monocytes. Since we have shown that PCPA inhibits the production of IFN $\gamma$ and IL-10, we may hypothesize that endogenous 5-HT exerts an autocrine and necessary role in the secretion of those cytokines. In this respect, Aune et al. (1994) showed that endogenous 5-HT was indispensable for human $\mathrm{T}$ cell proliferation. PCPA at the same concentrations as employed in the present study $(5 \mu \mathrm{M})$ inhibited the proliferative responses of $\mathrm{T}$ cells to polyclonal activators, whereas the inhibition of $\mathrm{T}$ cell proliferation by PCPA was reversed by 5-HTP (Aune et al. 1994). Thus, intracellular 5-HT may be necessary for an optimal synthesis of IFN $\gamma$ and IL-10, whereas extracellular 5-HT concentrations at or above serum values may suppress the production of the proinflammatory cytokine IFN $\gamma$.

The third major finding of this study revolves around the immunoregulatory effects of 5-HT1A and 5-HT2 re- ceptor agonists and antagonists. A number of 5-HT receptor subtypes have been identified on immunocytes. Serotonergic receptors on leukocytes were already demonstrated in 1982 (Eliseeva and Stefanovich 1982). Functional, pharmacological, biochemical, and molecular analyses have identified the 5HT1A receptor on human NK cells and activated PBMC and T cells (Aune et al. 1993, 1994; Hellestrand et al. 1993). Pharmacological and molecular analyses demonstrated the presence of 5HT2C receptors on human activated T lymphocytes. In the present study, no significant effects of flesinoxan, a 5-HT1A agonist, on IFN $\gamma$ or IL-10 production could be found. We found that ritanserin as well as mCPP significantly decrease the IFN $\gamma / \mathrm{IL}-10$ production ratio. In the case of ritanserin it is clear that this effect is obtained through inhibition of the IFN $\gamma$ production. 5HT2A/C antagonists in the murine model inhibit the passive transfer of DTH reactions (Gershon et al. 1975; Ameisen et al. 1989) and IFN $\gamma$-induced murine macrophage Ia expression (Sternberg et al. 1987). 5-HT2A/C antagonists modulate IFN $\gamma$-induced phagocytosis by murine macrophages (Sternberg et al. 1987). Arzt et al. (1991) reported that 5-HT inhibits-in a concentration dependent way - the LPS-induced production of tumor necrosis factor by human macrophages, and that this effect was blocked by the 5-HT2 receptor antagonist, ketanserin. On the other hand, 5-HT2A/C receptor antagonists were not able to inhibit PHA-stimulated proliferation of T cells (Aune et al. 1994; Nordlind et al. 1992). Enhancement of murine T-cell blastogenesis by 5-HT has been shown to occur through 5-HT2 receptors (Young et al. 1993). The production of Th- 1 cytokines, such as IL-2 and IFN $\gamma$, by Ag-stimulated, immune murine spleen cells is inhibited by 5HT1A receptor antagonists, but not by 5 HT2 receptor antagonists (Aune et al. 1994).

Our observations further underscore the role of 5-HT in the production rate of proinflammatory (IFN $\gamma$ ) versus negative immunoregulatory (IL-10) cytokines and may suggest an involvement of the $5 \mathrm{HT} 2 \mathrm{~A} / \mathrm{C}$, but not $5-\mathrm{HT} 1 \mathrm{~A}$, receptors in 5-HT-mediated IFN $\gamma$ versus IL-10 production. However, also the role of 5-HT2A/C related mechanisms for the production of IFN $\gamma$ versus IL-10 appears inconclusive since both agonists and antagonists at these receptor sites have similar effects on the IFN $\gamma$ / IL-10 production ratio. Perhaps the effects of mCPP may in part be explained by its 5-HT reuptake inhibitory effects (Baumann et al. 1995) or its activity at other 5-HT receptors, such as the 5-HT1D sites (Schoeffter and Hoyer 1989). Moreover, $\mathrm{mCPP}$ has been shown to bind to $\alpha 2$-adrenergic receptors (Hamik and Peroutka 1989). Stimulation of $\alpha 2$-adrenenoceptors may result in negative immunoregulatory effects (Maes et al. unpublished data).

Our results that 5-HT2A/C receptor antagonists and agonists do not modulate the production rate of IL-10 suggest that the negative immunoregulatory effects of 
SSRIs and TCAs, which may in part exert their antidepressant efficacy through their activity at 5-HT2A/C receptors (see review in Maes et al. 1997), may not be ascribed to 5-HT2A/C mechanisms.

Future research should focus on the effects of antidepressants and serotonergic agents on cyclic AMP (cAMP). Xia et al. (1996) reported that TCAs as well as SSRIs significantly elevate intracellular cAMP concentrations in T lymphocytes and monocytes. Elevation of the intracellular levels of cAMP differently affects the production of IL-10 and IFN $\gamma$ (Benbernou et al. 1997). cAMP-elevating agents inhibit IFN $\gamma$ mRNA expression and IFN $\gamma$ levels in lymphocytes, and significantly enhance IL-10 mRNA expression and the intracellular levels of IL-10 (Benbernou et al. 1997). In monocytes, cAMP elevating drugs augment the stimulated synthesis of IL-10 at both protein and mRNA levels (Platzer et al. 1995). 5-HT stimulates cAMP formation in homogenates of rat hippocampus in a concentration-dependent manner; 5-HT1A, 5-HT7, and 5-HT4 receptors are involved in mediating these responses (Markstein et al. 1999).

In the present study we found that the production of IFN $\gamma$ was significantly lower in older than in younger volunteers and that the production of IFN $\gamma$ was significantly higher in fluoxetine-treated TRD patients than in age-matched normal volunteers. The differences between both age-groups may be explained by the previous findings that ageing is associated with various alterations in lymphoid cell functioning, such as decreased IFN $\gamma$ production (Candore et al. 1993). The higher IFN $\gamma$ production in depressed patients treated with fluoxetine could perhaps be explained by previous findings that IFN $\gamma$ production is significantly increased in depressed patients and that IRS activation is more pronounced in patients with TRD despite antidepressive treatment (see review in Maes 1997; Seidel et al. 1995). However, the data presented are for a small cohort of subjects. Moreover, the study groups do not include a spectrum of older individuals and drug-free depressed patients.

Although the data suggest differences between the younger and older normal volunteers and depressed patients following fluoxetine, a larger cohort of young and old individuals and drug-free depressed patients should be studied in order to establish valid conclusions. In addition, it should be stated that this study employed diluted whole blood stimulated with PHA + LPS to study the effects of drugs on the production of cytokines. It is conceivable that comparable results will be obtained using other polyclonal activators. Nevertheless, diluted whole blood stimulated with LPS + PHA offers the most appropriate and reproducible culture condition in order to measure cytokine production and to study the effects of any drugs on the production of cytokines (Zangerle et al. 1992; De Groote et al. 1992, 1993).

\section{ACKNOWLEDGMENTS}

The research reported was supported by the Flemish Community, Belgium; the Funds for Scientific Research, Vlaanderen, Belgium (FWO); the Clinical Research Center for Mental Health, (CRC-MH), Antwerp, Belgium; the Staglin Investigator Award (NARSAD, USA) to Dr. M. Maes, and grant no. PO5A098-12 from the Committee on Scientific Research, Poland. The assistance of E. Nowak, Mrs. M. Maes, and R. Bullock are acknowledged.

\section{REFERENCES}

Ameisen J-C, Meade R, Askenase PW (1989): A new interpretation of the involvement of serotonin in delayedtype hypersensitivity: Serotonin-2 receptor antagonists inhibit contact sensitivity by an effect on $\mathrm{T}$ cells. J Immunol 142:3171-3179

American Psychiatric Association (1994): Diagnostic and Statistical Manual of Mental Disorders. 4th Ed. Washington DC, American Psychiatric Association

Arzt E, Costas M, Finkielman S, Nahmod VE (1991): Serotonin inhibition of tumor necrosis factor-alpha synthesis by human monocytes. Life Sci 48:2557-2562

Aune TM, McGrath KM, Sarry T, Bombara MP, Kelley KA (1993): Expression of 5HT1a receptors on activated human T cells. J Immunol 151:1175-1183

Aune MT, Golden HW, McGrath KM (1994): Inhibitors of serotonin synthesis and antagonists of serotonin 1A receptors inhibit $\mathrm{T}$ lymphocyte function in vitro and cell-mediated immunity in vivo. J Immunol 153:489-498

Baumann MH, Mash DC, Staley JK (1995): The serotonin agonist m-chlorophenylpiperazine (mCPP) binds to serotonin transporter sites in human brain. Clin Neurosci Neuropathol 6:2150-2152

Benbernou N, Esnault S, Shin HCK, Fekkar H, Guenounou M (1997): Differential regulation of IFN- $\gamma$, IL-10 and inducible nitric oxide synthase in human $\mathrm{T}$ cells by cyclic AMP-dependent signal transduction pathway. Immunology 91:361-368

Bluthé RM, Crestani F, Kelley KW, Dantzer R (1992): Mechanisms of the behavioral effects of interleukin 1. Ann NY Acad Sci 650:268-275

Bonnet M, Lespinats G, Burtin C (1984): Histamine and serotonin suppression of lymphocyte response to phytohemagglutinin and antigen. Cell Immunol 83:280-291

Boranic M, Pericic D, Poljak-Blazi M, Sverko V, Marotti T (1987): Suppression of immune response in rats by stress and drugs interfering with metabolism of serotonin. Ann NY Acad Sci 496:485-491

Candore G, Di Lorenzo G, Melluso M, Cigna D, Colucci AT, Modica MA, Caruso C (1993): Gamma-Interferon, interleukin-4 and interleukin-6 in vitro production in old subjects. Autoimmunity 16:275-280

Cavaillon J-M (1996): Les Cytokines. Paris, Masson

Cohen RAJ, Zitnay KM, Weisbrod RM (1985): Plateletinduced neurogenic coronary contraction due to accu- 
mulation of the false neurotransmitter, 5-hydroxytryptamine. Clin Invest 75:286-292

Connor TJ, Leonard BE (1998): Depression, stress and immunological activation: The role of cytokines in depressive disorders. Life Sci 62:583-606

De Groote D, Zangerle PF, Gevaert Y, Fassotte MF, Beguin Y, Noizat-Pirenne F, Pirenne J, Gathy R, Lopez M, Dehart I, Igot D, Baudrihaye M, Delacroix D, Franchimont P (1992): Direct stimulation of cytokines (IL-1 $\beta$, TNF- $\alpha$, IL-6, IL-2, IFN- $\gamma$ and GM-CSF) in whole blood. I. Comparison with isolated PBMC stimulation. Cytokine 4:239-248

De Groote D, Gevaert Y, Lopez M, Gathy R, Fauchet F, Dehart I, Jadoul M, Radoux D, Franchimont P (1993): Novel method for the measurement of cytokine production by one-stage procedure. J Immunol Meth 9:259-267

Devoino LV, Korovina LS, Ilyutchenok RY (1968): Influence of some drugs on the immune response. I. The effect of 5-hydroxytryptophan, iproniazid and reserpine on primary and secondary immune responses Eur J Pharmacol 4:441-448

Devoino LV, Morozova NB (1988): Serotoninergic system in neuroimmunomodulation: Mechanism of inhibition. In Novera HS (ed), Neuroimmunomodulation, Proceedings of the First International Workshop, Bethesda, 2730 November 1984. New York, Gordon and Breach Sciences Publishers, pp 119-123

Eliseeva LS, Stefanovich LE (1982): Specific binding of serotonin by blood leukocytes and peritoneal cells in the mouse. Biokhimiia 47:810-813

Essmann WB (1978): Serotonin distribution in tissue and fluids. In WB Essmann (ed), Serotonin in Health and Disease, Vol. 1. New York, Spectrum, pp 85-91

Felten DL, Cohen N, Ader R, Felten SY, Carlson SL, Roszman TL (1991): Psychoneuroimmunology. In Ader R, Felten DL, Cohen N (eds), Psychoneuroimmunology. San Diego, Academic Press, pp 1-26

Finocchiaro LME, Arzt ES, Fernandez-Castelo S, Criscuolo M, Finkielman S, Nahmod VE (1988): Serotonin and melatonin synthesis in peripheral blood mononuclear cells: Stimulation by interferon-g as part of an immunomodulatory pathway. J Interferon Res 8:705-716

Gershon RK, Askenase PW, Gershon MD (1975): Requirement for vasoactive amines for production of delayed-type hypersensitivity skin reactions. J Exp Med 142:732-747

Hamik P, Peroutka S (1989): mCPP interactions with neurotransmitter receptors in the human brain. Biol Psychiatry 25:569-575

Hamilton M (1960): A rating scale for depression. J Neurol Neurosurg Psychiatry 23:56-61

Hellestrand K, Czerkinsky C, Ricksten A, Jansson B, Asea A, Kylefjord H, Hermodsson S (1993): Role of serotonin in the regulation of interferon-gamma production by human natural killer cells. J Interferon Res 13:33-38

Jackson JC, Cross RJ, Walker RF (1985): Influence of serotonin on the immune response. J Immunol 54:505-513

Jahnova E (1994): The effect of risperidone and ritanserin on human IgG and IgM synthesis in vitro. Physiol Res 43:27-31
Katsikis PD, Cohen SB, Londei M, Feldmann M (1995): Are CD4+ Th1 cells pro-inflammatory or anti-inflammatory? The ratio of IL-10 to IFN-gamma or IL-2 determnines their function. Intl Immunol 7:1287-1294

Kubera M, Maes M (1999): Serotonin-immune interactions in major depression. In Patterson PH, Kordon C, Christen Y. Fondation IPSEN (eds), Neuroimmune Interactions in Neurologic and Psychiatric Disorders. New York, Springer Verlag, pp 79-88

Lin A, Song C, Kenis G, Bosmans E, De Jongh R, Scharpe S, Maes M: The in vitro immunosuppressive effects of moclobemide. J Affect Disord (In press)

Maes M (1997): The immune pathophysiology of major depression. In Honig A, van Praag H (eds), Depression: Neurobiological, Psychopathological and Therapeutic Advances. Chichester, John Wiley, pp 197-215

Maes M, Meltzer HYM (1995): The serotonin hypothesis of major depression. In Bloom F, Kupfer D (eds), Psychopharmacology: The Fourth Generation of Progress. New York, Raven Press, pp 933-944

Maes M, Smith R, Scharpe S (1995): The monocyte-T-lymphocyte hypothesis of major depression. Psychoneuroendocrinology 20:111-116

Maes M, Delanghe J, Ranjan R, Meltzer HY, Desnyder R, Cooreman W, Scharpe S (1997): The acute phase protein response in schizophrenia, mania and major depression: Effects of psychotropic drugs. Psychiatry Res 66:1-11

Maes M, Song C, Lin A, De Jongh R, Van Gastel A, Kenis G, Bosmans E, De Meester I, Benoy I, Neels H, Demedts P, Janca A, Scharpe S, Smith RS (1998): The effects of psychological stress on humans: Increased production of pro-inflammatory cytokines and a Th1-like response in stress-induced anxiety. Cytokine 10:313-318

Maes M, Song C, Lin A-H, Bonaccorso S, Kenis G, De Jongh R, Bosmans E, Scharpe S (1999): Negative immunoregulatory effects of antidepressants: Inhibition of interferon- $\gamma$ and stimulation of interleukin-10 secretion. Neuropsychopharmacology 20:370-379

Markstein R, Matsumoto M, Kohler C, Togashi H, Yoshioka M, Hoyer D (1999): Pharmacological characterization of 5-HT receptors positively coupled to adenyl cyclase in the rat hippocampus. Naunyn Schiedebergs Arch Pharmacol 359:454-459

Mossner R, Lesch K-P (1998): Role of serotonin in the immune system and in neuroimmune interactions. Brain Behav Immun 12:249-271

Murray PJ, Wang L, Onufryk C, Tepper RI, Young RA (1997): $T$ cell-derived IL-10 antagonizes macrophage function in mycobacterial infections. J Immunol 158:315-321

Nordlind K, Sundstrom E, Bondesson L (1992): Inhibiting effect of serotonin antagonists on the proliferation of mercuric chloride stimulated human peripheral blood $\mathrm{T}$ lymphocytes. Intl Arch Allergy Immunol 87:105-108

Platzer C, Meisel C, Vogt K, Platzer M, Volk HD (1995): Upregulation of monocytic IL-10 by tumor necrosis factoralpha and cAMP elevating drugs. Intl Immunol 7:517

Ptak W, Geba GP, Askenase PW (1991): Initiation of delayed-type hypersensitivity by low doses of monoclonal IgE antibody. Mediation by serotonin and inhibition by histamine. J Immunol 146:3929-3936 
Roszman TL, Jackson JC, Cross RJ, Titus MJ, Markesbery WR, Brooks WH (1985): Neuroanatomic and neurotransmitter influences on immune function. J Immunol 135:769S-772S

Schoeffter P, Hoyer D (1989): Interaction of arylpiperazines with 5-HT1A, 5-HT1B, 5-HT1C and 5-HT1D receptors: Do discriminatory 5-HT1B receptor ligands exist? Arch Pharmacol 339:675-683

Seidel A, Arolt V, Hunstiger M, Rink L, Behnisch A, Kirchner H (1995): Cytokine production and serum proteins in depression. Scand J Immunol 41:534-538

Sluzewska A, Rybakowski JK, Laciak M, Mackiewicz A, Sobieska M, Wiktorowicz K (1995): Interleukin-6 serum levels in depressed patients before and after treatment with fluoxetine. Ann Acad Sci 762:474-476

Spitzer RL, Williams JBW, Gibbon M, First MB (1990): Structured Clinical Interview According to DSM-III-R. New York, American Press

Sternberg EM, Wedner HJ, Leung MK, Parker CW (1987): Effect of serotonin (5-HT) and other monoamines on murine macrophages: Modulation of interferon-gamma induced phagocytosis. J Immunol 138:4360-4365
Xia Z, DePierre JW, Nassberger L (1996): Tricyclic antidepressants inhibit IL-6, IL-1 $\beta$ and TNF- $\alpha$ release in human blood monocytes and IL-2 and interferon- $\gamma$ in T cells. Immunopharmacology 34:27-37

Yirmiya R (1996): Endotoxin produces a depressive-like episode in rats. Brain Res 711:163-174

Yirmiya R (1997): Behavioral and psychological effects of immune activation: Implications for depression due to a general medical condition. Curr Opin Psychiatry 10:470-476

Young MRI, Kut JL, Coogan MP, Wright MA, Young ME, Matthews J (1993): Stimulation of splenic T-lymphocyte function by endogenous serotonin and by low-dose exogenous serotonin. Immunology 80:395-400

Young MRI, Matthews JP (1995): Serotonin regulation of T-cell subpopulations and of macrophage accessory function. Immunology 84:148-152

Zangerle PF, De Groote D, Lopez M, Meuleman RJ, Vrindts Y, Fauchet F, Dehart I, Jadoul M, Radoux D, Franchimont P (1992): Direct stimulation of cytokines (IL-1 beta, TNF-alpha, IL-6, IL-2, IFN-gamma and GM-CSF) in whole blood. II. Application to rheumatoid arthritis and osteoarthritis. Cytokine 4:568-575 